\title{
КОЛЧЕДАННЫЕ МЕСТОРОЖДЕНИЯ ЭНСИМАТИЧЕСКИХ ОСТРОВНЫХ ДУГ КАЗАХСТАНА НА ПРИМЕРЕ МЕСТОРОЖДЕНИЯ АБЫЗ
}

\author{
Мазуров Алексей Карпович1, \\ akm@tpu.ru
}
Рудмин Максим Андреевич1, rudminma@tpu.ru

Байболова Шынар Жуматаевна², baibolova-sh@mail.ru

\author{
Кряжева Татьяна Владимировна², \\ kryazheva_t@mail.ru \\ 1 Национальный исследовательсий Томский политехнический университет, \\ Россия, 634050, г. Томск, пр. Ленина, 30. \\ 2 Карагандинский государственный технический университет, Казахстан, \\ 100027, г. Караганда, пр. Нурсултана Назарбаева, 56/1.
}

\begin{abstract}
Актуальность исследования определяется необходимостью освещения новых данных по формированию колчеданного оруденения (Au-Cu-Pb-Ag) в энсиматических островных дугах поздней стадии развития. Проведенные исследования показали, что перспективы энсиматических островных дуг полностью не исчерпаны.

Цель: изучить петрологические, геохимические особенности пород и вещественный состав руд для уточнения прогнознопоисковых критериев при прогнозировании и поисках колчеданного оруденения в энсиматических островодужных геологических образованиях.

Методы исследования включали изучение состава горных пород и руд с использованием классического минералогического, петрографического и минераграфического анализов и сканирующей электронной микроскопии. Химический состав пород определялся с помощью силикатного анализа. Данные химического анализа были пересчитаны по кислородному методу Т. Барта для определения привноса и выноса химических элементов.

Результаты. Колчеданные месторождения Казахстана в основном формировались в островодужной геодинамической обстановке. Островодужные палеосистемы Казахстана подразделяются на энсиматические и энсиалические. С энсиалическими островными дугами связано формирование Рудноалтайского полиметаллического пояса. Месторождение Абыз связано с формированием энсиматической островной дуги поздней стадии развития. Островодужное основание заложено на океанической коре и представлено преимущественно осадочными породами: вулканомиктовыми и полимиктовыми песчаниками, конгломератами и алевролитами. Породы, слагающие месторождение, подверглись интенсивному гидротермально-метасоматическому изменению, выразившемуся в пропилитизации и березитизации. В результате метасоматических процессов на месторождении было сформировано 13 рудных тел. Морфология рудных тел довольно сложная, формы линзовидные, линзовидно-пластовые. Основными минералами массивных колчеданных руд являются: халькопирит, пирит, ссралерит, галенит, блеклые руды, теллуриды (альтаит, раклиджит) и включения золота. Содержание серебра в золоте достигает 12,5%.
\end{abstract}

\section{Ключевые слова:}

Колчеданные месторождения, энсиматические островные дуги, золоторудная минерализация, гидротермальнометасоматические изменения, прогнозно-поисковье критерии, Казахстан.

\section{Введение}

В балансе добычи свинца, цинка и меди колчеданные месторождения вулканической ассоциации играют значительную роль [1-10]. Практически каждая тектоническая провинция, имеющая в своем составе в качестве важной составляющей субмаринные вулканические породы, содержит, по крайней мере, небольшие месторождения колчеданных руд [2, 10-16]. Наиболее крупные $\mathrm{Cu}-\mathrm{Pb}-\mathrm{Zn}$ месторождения, которые относят к типу колчеданов, в настоящее время известны в следующих горно-рудных районах: Иберийский пиритный пояс, Урал, Рудный Алтай, зеленокаменные пояса Абитиби и Черчилл на Канадском щите, Британская Колумбия, Аппалачи и пояс Маунт-Рид на Тасмании [2, 3, 12, 17, 18]. В перечисленных выше провинциях сосредоточено около 75 \% всех мировых запасов кол- чеданных руд. Из колчеданных месторождений добывается не только подавляющее количество меди, цинка и свинца (10-15\% мировой добычи), но и существенные объемы золота, серебра и редкоземельных металлов. Образование колчеданных месторождений происходило с раннего архея непрерывно до позднего кайнозоя и генетически связано с подводно-морскими вудканогенными образованиями. Формирование наиболее крупных по запасам металлов месторождений происходило в периоды резкого сокращения вулканической деятельности. Анализ закономерностей размещения колчеданных месторождений показал, что они формировались в разнообразных геодинамических обстановках. По ряду признаков большинство исследователей выделяет четыре типа колчеданных месторождений: кипрский, уральский, Куроко и Бесши [5, 6, 19-31]. 
Для Казахстана характерны колчеданные месторождения двух типов: Куроко и уральский, которые формировались в основном в островодужной геодинамической обстановке. Анализ материалов геологических съемок масштабов 1:200000 и мельче позволил разделить все островодужные палеосистемы Казахстана на энсиматические и энсиалические. Г.Ф. Ляпичев предложил энсиматические образования считать первичными, а энсиалические, которые включают блоки более ранней континентальной коры, а океаническое основание в них не отмечается, - вторичными. По геологическим формациям, слагающим островодужные образования, в каждой группе выделяются островные дуги ранней и поздней стадий развития.

Уникальные месторождения Восточного Казахстана, которые образуют Рудноалтайский полиметаллический пояс, связаны с формированием энсиалических остравных дуг. Открытые в пределах пояса месторождения характеризуются не только крупнейшими в мире концентрациями полиметаллических руд, но и значительными запасами серебра и золота $[8,11,17,32]$. Геологическое строение, тектоника и магматизм, а также условия формирования и вещественный состав конкретных месторождений Рудноалтайского полиметаллического пояса изучены достаточно полно. В изучение как в целом территории, так и отдельных месторождений существенный вклад внесли работы известных исследователей: В.В. Авдонина, Д.Г. Ажгирея, В.Д. Баранова, Э.Н. Баранова, Х.А. Беспаева, Н.Л. Бубличенко, Г.П. Болгова, Б.Н. Вейц, Д.М. Воинова, Ю.Ю. Ворбьева, Г.Д. Ганженко, А.А. Гармаша, Д.И. Горжевского, Ю.И. Демина, И.В. Дербикова, Н.И. Еремина, П.Ф. Иванкина, В.Д. Инина, П.В. Иншина, И.З. Исакович, А.К. Каюпова, О.А. Ковриго, В.А. Комар, М.С. Козлова, И.В. Крейтер, В.С. Кузебнова, В.В. Кузнецова, А.С. Лапухова, М.Ф. Микунова, Н.М. Митряевой, В.А. Наумова, В.П.Нехорошева, И.В. Покровской, Э.С. Пономарева, В.И. Старостина, Н.И. Стучевского, М.А. Тойбазарова, Л.М. Трубникова, Е.И. Филатова, М.Г. Хисамутдинова, В.М. Чекалина, Г.Н. Щербы, Г.Ф. Яковлева и многих других $[8,9,17,18,32-36]$.

При составлении минерагенической карты Казахстана масштаба 1:2500000 к энсиматическим островным дугам ранней стадии развития нами были отнесены следующие металлогенические зоны: Иргизская, Федоровская, Бестюбинская, Бозшакольская, Жалаирнайманская, Шингиз-Тарбагатайская и БестауКокпектинская. Основанием для отнесения указанных зон к раннему этапу развития послужило наличие в основании островодужных образований вулканогенных или осадочных формаций океанического дна (базальты, кремнисто-терригенные породы). Вулканогенные толщи представлены породами преимущественного основного, реже среднего и кислого состава, перемежающимися с осадочными породами. Основание разреза, как правило, сложено преимущественно вулканогенными породами с прослоями осадочных пород. Количество прослоев осадочных пород и их мощность меняется в широких пределах, но для всех изученных разрезов выдерживается тенденция к увеличению осадочных пород к верхам разреза. Интрузивные породы представлены в основном разностями повышенной основности: габброидами, диоритами, гранодиоритами, плагиогранитами, реже гранитами, граносиенитами, ультраосновными разностями. Оруденение комплексное медно-молибденовое с золотом. Отдельные исследователи отмечали наличие в описываемых рудах платиноидов.

Майкаинская, Сувенир-Касмурунская, Абралинская и Сарытумская металлогенические зоны нами отнесены к энсиматическим остравным дугам поздней стадии развития. Заложены дуги позднего этапа развития, как и раннего этапа развития, на океанической коре, но островодужные образования в них представлены преимущественно осадочными породами: вулканомиктовыми и полимиктовыми песчаниками, конгломератами, алевролитами, линзами известняков. Их разрез фактически повторяет верхи разреза энстиматических островных дуг ранней стадии развития. Интрузивные породы представлены плагиогранитами, гранодиоритами, диоритами, габбро, иногда ультромафитами. К настоящему времени известно более двадцати месторождений, которые связанны с поздней стадией развития энсиматических островных дуг. Минеральный состав руд в основном представлен: пиритом, галенитом, сфалеритом и халькопиритом. При составлении минерагенической карты нами были выделены следующие металлогенические комплексы: медно-свинцово-цинково-золотые, риолит-трахириолит-андезит-базальтовые, нижнесредне-ордовикские Кумустинский, Торткудукский и Майкаинский; верхнеордовикский: Космурунский. Шатыркульский золото-медный гранодиоритгранитный ордовикский металлогенический комплекс нами также отнесен к поздней островодужной стадии развития, но с большой долей условности. Наибольший практический интерес представляют месторождения Майкаинского, Космурунского и Торткудукского металлогенических комплексов.

Целью данной работы является изучение условий формирования колчеданного оруденения энсиматических островных дуг для определения перспектив развития минерально-сырьевой базы Центрального Казахстана.

\section{Объект исследования}

В пределах образований энсиматических островных дуг выявлено более двух десятков колчеданнополиметаллически-золотых месторождений - Майкаин, Торткудук, Акбастау, Кусмурун, Сувенир, Алпыс, Александровское, Абыз и др. Объектом исследования послужили руды и породы месторождения Абыз (рис. 1, а, 49²1'0" с.ш. $76^{\circ} 32$ 24" в.д.). Колчеданное полиметаллически-золотое месторождение Абыз $[8,11,33,35]$ можно считать репрезентативным объектом для изучения и оценки других месторождений, которые к настоящему времени выявлены или будут обнаружены в процессе дальнейших поисковых работ. Месторождение Абыз расположено в Карагандинской 
области Республики Казахстан в 30 км к западу от рудника Кентюбе, связанного 30 километровой железнодорожной веткой с основной магистралью Карагайлы-Караганда.

В геологическом строении месторождения (рис. 1) принимают участие вулканогенно-осадочные отложения девона, прорванные интрузивными и субвулканическими образованиями средне-основного состава. Палеозойский фундамент площади месторождения на 80 \% перекрыт чехлом рыхлых кайнозойских отложений мощностью от $5 \ldots 10$ до $40 \ldots 50$ м. Считалось, что девонские отложения залегают моноклинально и имеют крутое падение на запад (рис. 1, b). Проведенное литологическое расчленение этих отложений на две толщи: нижнюю и верхнюю, а последней на две пачки: базальтоидную и туфовою, позволило выявить в пределах западной части месторождения брахисинклинальную структуру, выполаживающуюся к югу. В восточной части месторождения породы нижней толщи слагают опрокинутую антиклинальную складку, также погружающуюся к югу. Опрокинутая антиклинальная складка осложнена долго живущим Восточным разломом субмеридионального направления, разделяющим вулканогенно-осадочные отложения нижней толщи от верхней. Породы западного крыла синклинали характеризуются относительно пологим падением $\left(45 \ldots .55^{\circ}\right)$ на восток, крыло осложнено двумя тектоническими нарушениями типа взбросов. (a)

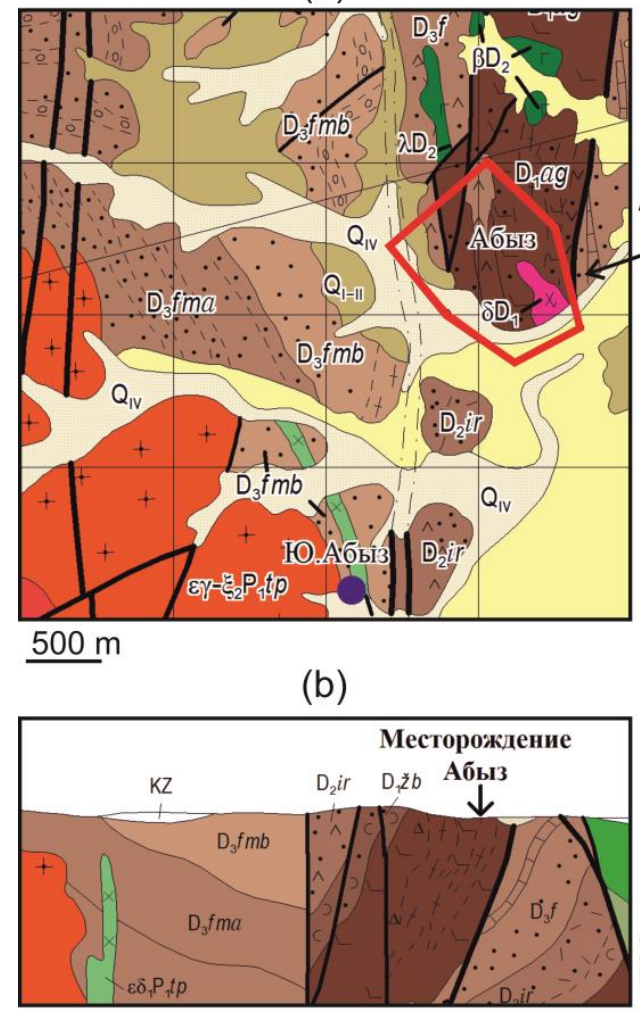

Условные

обозначения /

Legend

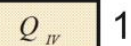

Абыз/Abyz

Рис. 1. Схематическая геологическая карта месторождения Абыз (а) и схематический геологический разрез (b). Условные обозначения: 1 - четвертичная система (голочен), аллювиальные и озерные пески, галечники, супеси, суглинки, глины; девонская система: 2 - фаменский ярус (верхняя пачка), известковисто-кремнистые тонкослоистые алевролиты с прослоями известняков; 3 - фаменский ярус (нижняя пачка), алевролиты и песчаники сероцветные, реже красночветные; 4 - верхний отдел (франский ярус), песчаники и алевролить темно-серые с линзами органогенно-обломочных известняков; 5 - средний отдел (иргалинская свита), риолитовые, риодацитовые порфиры и их туфы, ингимбриты, прослои туфопесчаников; 6 - нижний отдел (айгыржальская свита), андезибазальтовые порфириты и их туфы, туфопесчаники, туфоалевролиты, риолиты и базальты; субвулканические образования: 7 -среднедевонские долериты и долеритовые порфириты; 8 - среднедевонские риолиты, трахидациты и даџиты; интрузивные образования: 9 - топарский комплекс (вторая фаза внедрения), квариевые сиениты, граниты субщелочные мелкозернистые

Fig. 1. Simplified geological map of the Abyz deposit (a) and simplified geological section (b). Legend: 1 - Quaternary system (Holocene), alluvial and lake sands, pebbles, sandy loam, loam, clay; Devonian system: 2 - Famennian Stage (upper member), calcareous-siliceous thin-layer siltstones with limestone interbeds; 3 - Famennian Stage (lower member), siltstones and sandstones are gray-colored, less often red-colored; 4 - upper series (French Stage), sandstones and siltstones dark gray with lenses of organogenic clastic limestones; 5 - middle series (Irgalinskaya Stage), rhyolitic, rhyodacite porphyries and their tuffs, ingimbrites, tuff sandstones interbeds; 6 - lower series (Aygirzhal Stage), andesibasalt porphyrites and their tuffs, tuff sandstones, tuff siltstones, rhyolites and basalts; subvolcanic formations: 7 - Middle Devonian dolerites and dolerite porphyrites; 8 - Middle Devonian rhyolites, trachidocytes and dacites; intrusive formations: 9 - Toparsky complex (second phase of intrusion), quartz syenites, subalkaline fine-grained granites 


\section{Материал и методика исследования}

Месторождение изучалось скважинами колонкового бурения (109595 м), шурфами (75 м) и комплексом подземных горных выработок (3492 м). Bсе скважины и горные выработки были подвергнуты химическому опробованию. Из керновых и бороздовых проб были изготовлены прозрачные и полированные шлифы, которые в дальнейшем изучались с использованием классического минералогического анализа, петрографического и рудного микроскопов и сканирующей электронной микроскопии (СЭМ). Силикатный анализ 138 керновых проб (весом от 2,7 до 4,0 кг), истертых до фракции менее 0,074 мм, выполнялся химическим методом в Центральной лаборатории ПГО «Центрказгеология» г. Караганда. СЭМ производилось с использованием микроскопа TESCAN VEGA 3 SBU, оснащенного приставкой для рентгенофлуоресцентного энергодисперсионного анализа (ЭДС) OXFORD X-Max 50 с Si/Li кристаллическим детектором.

\section{Результаты и обсуждения}

\section{Петрографо-минералогическая характеристика пород}

Породы, слагающие месторождение, подверглись интенсивному гидротермально-метасоматическому изменению, выразившемуся в пропилитизации и березитизации.

Пропилитовая формация проявлена слабо и охватывает самую внешнюю зону гидротермально-измененных пород в области влияния крупных разломов в западной части месторождения. Она выражается в относительно слабом изменении андезитов, андезитобазальтов, туфов и лавобрекчий средне-основного состава. Изменения заключаются в частичном либо полном псевдоморфном замещении минералов вкрапленников и основной массы пород. Эпигенетические минералы представлены альбитом, хлоритом, эпидотом, кварцем, в меньшей степени карбонатом, серицитом, актинолитом, пренитом, пумпелитом, лейкоксеном, пиритом и магнетитом. Для пропилитов весьма характерны пятнистые текстуры, обусловленные неравномерным распределением хлорита, эпидота и актинолита в виде пятен, различных по размерам и форме.

В пределах формации пропилитизированных пород выделяется несколько зон, характеризующихся развитием статистически устойчивых ассоциаций новообразованных минералов:

- зона развития альбит-хлоритовых и кварцхлоритовых ассоциаций с некоторым содержанием карбоната, прослеживается вдоль основных долгоживущих разломов;

- зона развития кварц-эпидотовых и хлоритэпидотовых ассоциаций с небольшим количеством серицита, карбоната, лейкоксена и пренита, приурочена к участкам повышенной проницаемости;

- зона развития высокотемпературных альбитактинолитовых и карбонат-актинолитовых ассоциаций, имеет весьма ограниченное (локальное) распространение.
Выделенные пропилитовые ассоциации образуют следующий возрастной ряд: альбит-хлоритовые $\rightarrow$ кварцхлоритовые $\rightarrow$ хлорит-эпидотовые $\rightarrow$ кварц-эпидотовые. Беризитовая гидротермально-метасоматическая формация проявлена на месторождении наиболее широко. По ряду признаков выделяется два типа парагенезиса беризитов.

Первый представлен кварц-светлослюдистыми образованиями, наиболее развит на месторождении. В пределах березитовой зоны выделяются серициткварцевые и кварц-серицитовые метасоматиты, в которых концентрируется пирит, образуя густовкрапленные и сплошные серно-колчеданные руды.

Второй представлен карбонат-серицитовыми и кварц-хлорит-карбонатными ассоциациями. Минеральные ассоциации данного типа проявлены в виде прожилковых и струйчатых выделений. С ними тесно ассоциирует пирит поздних генераций, отлагающийся в завершающейся стадии рудообразования в колчеданно-полиметаллических рудах и кварц-карбонатных прожилках.

В пределах выделенной минеральной ассоциации березитовой формации намечается следующий возрастной ряд: карбонат-серицитовые $\rightarrow$ кварц-хлорит-карбонатные $\rightarrow$ кварц-серицитовые $\rightarrow$ серицит-кварцевые.

Основные минералы колчеданных руд (рис. 2) представлены халькопиритом, пиритом, сфалеритом, галенитом, блеклыми рудами, теллуридами и включениями золота и пр. [37]. В общем виде в сульфидных рудах наблюдается постепенное выделение минералов в следующей последовательности: пирит, халькопирит, сфалерит, блеклые руды (минералы группы тетраэдрита) + галенит + теллуриды $\mathrm{Pb}$ и $\mathrm{Bi}$, реже $\mathrm{Ag}+$ золото. Золото (рис. 3) наблюдается в виде отдельных зёрен размером 1,5...10 мкм и приурочено к низкотемпературной ассоциации минералов с теллуридами $\mathrm{Pb}$ (алтаит, $\mathrm{PbTe}$ ) и $\mathrm{Bi}$ (раклиджит, $\left.\mathrm{PbBi}_{2} \mathrm{Te}_{4}\right)$. Содержание серебра в золотинках достигает $12,5 \%$. Гессит $\left(\mathrm{Ag}_{2} \mathrm{Te}\right)$ встречается в виде тонких зёрен (просечек) с халькопиритом, толщиной в несколько мкм, в пирите пропилитовой формации.

\section{Петрохимическая характеристика пород}

В целях изучения процессов, происходящих при образовании выделенных формаций, из каждой зоны отобраны пробы, которые затем были проанализированы в лаборатории Центрально-Казахстанского геологического объединения. Данные химического анализа были пересчитаны по кислородному методу Т. Барта (т. к. пористость пород не определялась). Результаты анализов проб и пересчета приведены в табл. 1,2 , соответственно. В результате проделанной работы установлено, что в процессе формирования пропилитовой формации происходит вынос кремния, натрия и калия и накопление кальция углерода, трехвалентного железа и частично магния. Поведение алюминия, титана, фосфора и марганца при метасоматическом изменении исходных пород остается не измененным во всех зонах. 

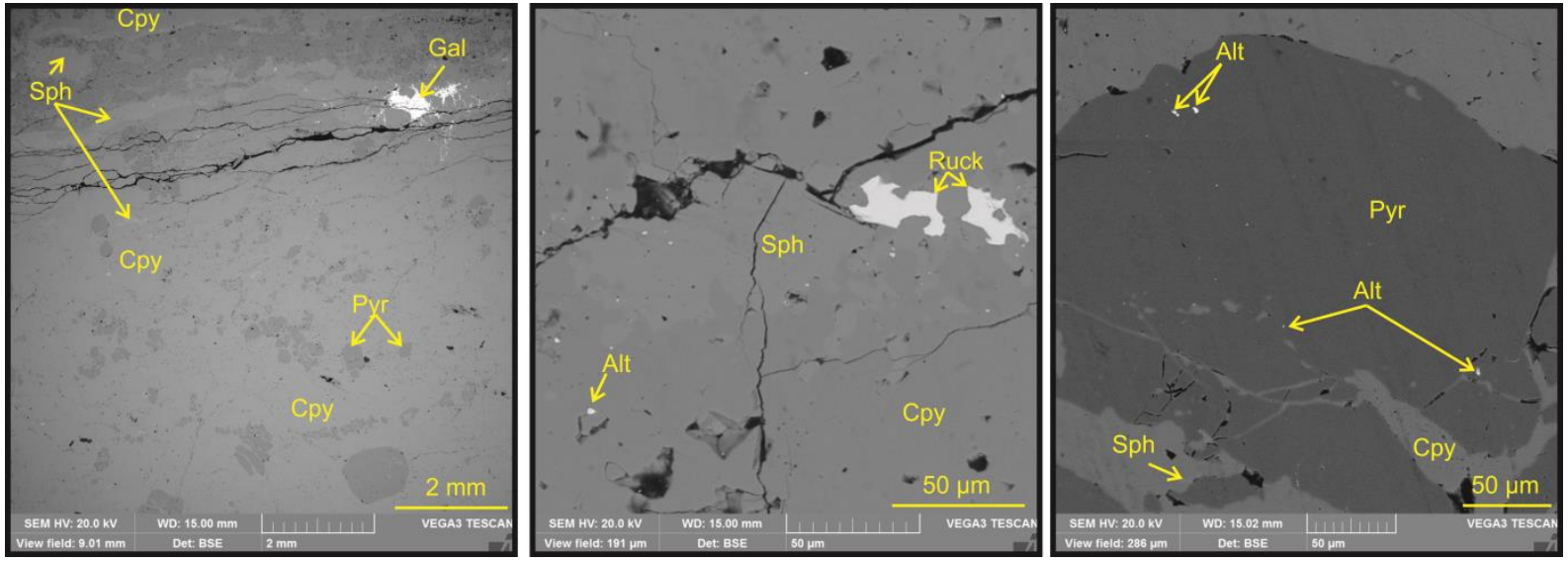

Pис. 2. СЭМ-снимки (снимки сканирующего электронного микроскопа) основной ассочиации минералов сульфидной (халькопиритовой) массивной рудь: Py - пирит, Сру - халькопирит, Sph - cфалерит, Gal - галенит, Alt алтаит, Ruck - раклиджит

Fig. 2. SEM-images (scanning electron microscopy images) of main mineral association in massive sulfide (chalcopyrite) ore: Py-pyrite, Cpy-chalcopyrite, Sph-sphalerite, Gal-galena, Alt-altaite, Ruck-rucklidgeite
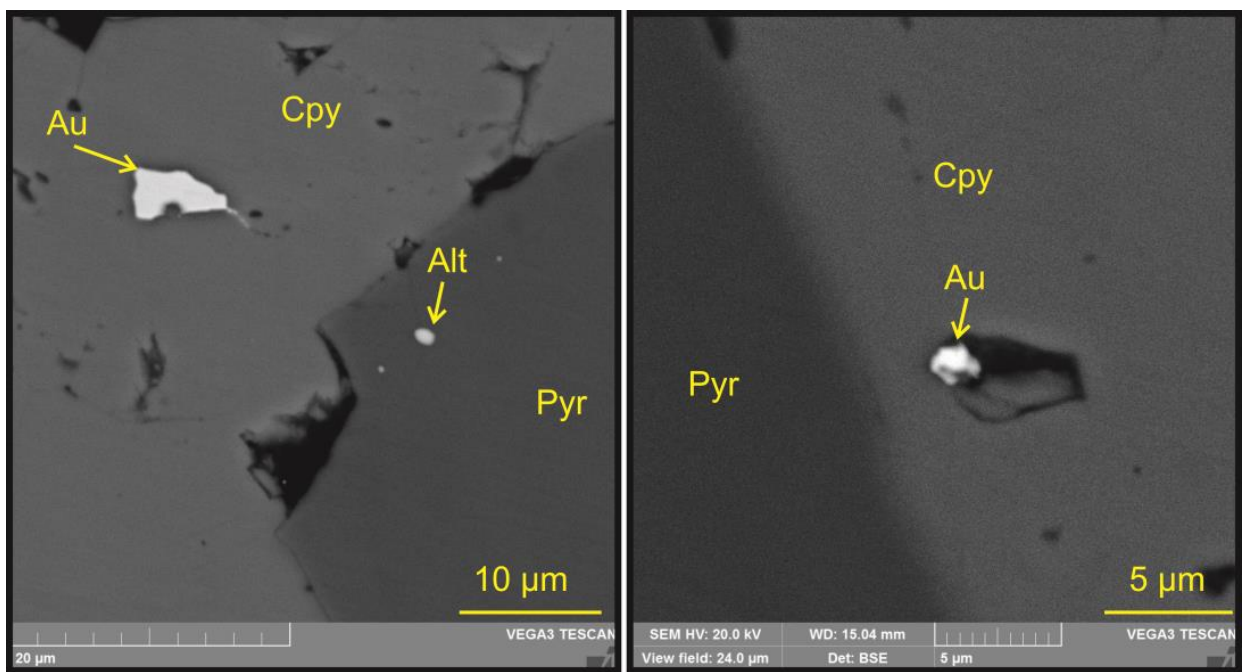

Pис. 3. СЭМ-снимки включений золота в сульфидных рудах: Au-gold, Py-pyrite, Cpy-Alt-altaite

Fig. 3. SEM-images of gold inclusions in sulfide ore: Au-gold, Py-pyrite, Cpy-Alt-altaite

При образовании березитовой минеральной ассоциации по андезитам происходит привнос калия, кремния и углерода, по андезитобазальтам - калия, кремния и частично алюминия. Остальные элементы при формировании березитовой формации выносятся. Преобладающий вынос щелочных и щелочноземельных катионов при высокой активности в реакциях замещения кремния и алюминия, доминирующий кварц-светлослюдистый парагенезис, устойчивый в кислой среде, позволяет говорить об образовании серицит-кварцевых метасоматитов в стадию кислотного выщелачивания. Формирование серициткварцевых метасоматитов сопровождалось образованием значительного количества пирита. Завершалось формирование метасоматитов образованием прожилков кварцевого и кварц карбонатного состава, которые пересекют руды и вмещающие породы.

В результате метасоматических процессов на месторождении было сформировано 13 рудных тел. Морфология рудных тел довольно сложная, формы линзовидные, линзовидно-пластовые. Как по паде- нию, так и по простиранию отмечаются раздувы и пережимы, изгибы, апофизы. Выклинивание в основном постепенное, плавное. Простирание рудных тел субмеридианальное, падение западное, юго-западное, углы падения от слабо наклонных $\left(35 \ldots 55^{\circ}\right)$ до крутых $\left(75 \ldots 90^{\circ}\right)$.

Основное рудное тело является самым крупным и выдержанным. В нем заключено 73 \% запасов руды Восточного участка и $65 \%$ Западного участка. В строении рудного тела участвуют как сплошные, так и вкрапленные сульфидные руды, распространение которых не имеет четкой закономерности. Как правило, сплошные руды приурочены к участкам раздувов и верхней части, нижняя часть рудного тела сложена в основном вкрапленными рудами. Контуры рудного в участках развития сплошных руд четкие и совпадают с геологическими границами метасоматитов. Вкрапленные руды не имеют четких геологических границ.

Руды комплексные, наряду с золотом в них присутствуют: серебро, медь, цинк, свинец, что отражается в их минеральном составе (рис. 2, 3). 
Известия Томского политехнического университета. Инжиниринг георесурсов. 2020. Т. 331. № 4. 28-37 Мазуров А.К. и др. Колчеданные месторождения энсиматических островных дуг Казахстана на примере месторождения Абыз

Таблица 1. Химический состав (вес. \%) пород месторождения Абыз

Table 1. Chemical composition (wt. \%) of rocks in Abyz deposit

\begin{tabular}{|c|c|c|c|c|c|c|c|c|c|c|}
\hline \multirow[b]{2}{*}{ 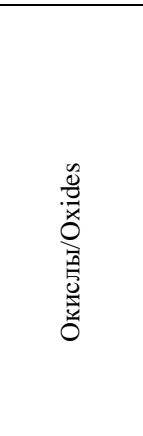 } & \multirow[b]{2}{*}{ 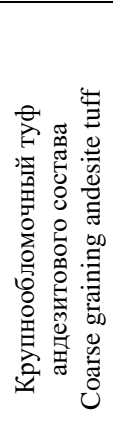 } & \multicolumn{4}{|c|}{$\begin{array}{l}\text { Метасоматиты по крупнообломочным туфам } \\
\text { андезитового состава } \\
\text { Metasomatites for coarse graining andesite tuff }\end{array}$} & \multirow[b]{2}{*}{ 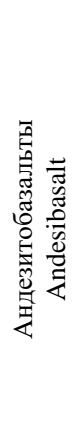 } & \multicolumn{4}{|c|}{$\begin{array}{l}\text { Метасоматиты по андезитобазальтам } \\
\text { Metasomatites for andesibasalt }\end{array}$} \\
\hline & & 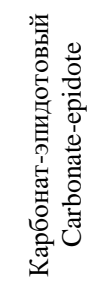 & 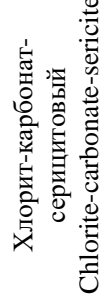 & 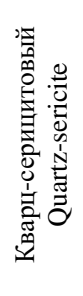 & 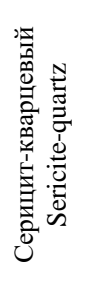 & & 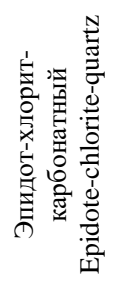 & 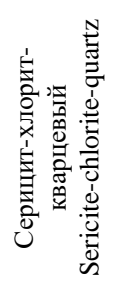 & 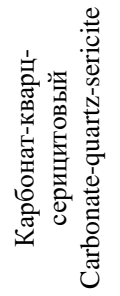 & 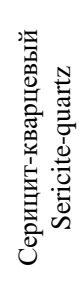 \\
\hline $\mathrm{SiO}_{2}$ & 58,36 & 44,85 & 56,12 & 64,72 & 71,41 & 44,48 & 40,84 & 57,25 & 61,48 & 66,20 \\
\hline $\mathrm{TiO}_{2}$ & 0,55 & 0,36 & 0,45 & 0,50 & 0,37 & 0,53 & 0,35 & 0,56 & 0,46 & 0,26 \\
\hline $\mathrm{Al}_{2} \mathrm{O}_{3}$ & 15,54 & 14,55 & 15,48 & 13,59 & 11,37 & 13,37 & 13,74 & 14,53 & 13,43 & 15,65 \\
\hline $\mathrm{Fe}_{2} \mathrm{O}_{3}$ & 3,19 & 6,67 & 2,14 & 1,25 & 5,54 & 4,76 & 6,51 & 2,78 & 3,85 & 1,81 \\
\hline $\mathrm{FeO}$ & 5,32 & 3,47 & 4,72 & 1,14 & 1,20 & 5,06 & 3,23 & 4,52 & 7,35 & 1,99 \\
\hline $\mathrm{MnO}$ & 0,093 & 0,22 & 0,14 & 0,026 & 0,02 & 0,265 & 0,15 & 0,14 & 0,28 & 0,052 \\
\hline $\mathrm{MgO}$ & 3,50 & 4,45 & 2,74 & 0,81 & 0,52 & 7,18 & 4,36 & 2,77 & 2,88 & 1,27 \\
\hline $\mathrm{CaO}$ & 2,54 & 15,09 & 5,66 & 0,72 & 0,51 & 8,8 & 18,75 & 5,68 & 1,03 & 3,07 \\
\hline $\mathrm{K}_{2} \mathrm{O}$ & 1,10 & 0,26 & 1,40 & 4,0 & 3,10 & 0,25 & 0,50 & 1,84 & 2,40 & 2,18 \\
\hline $\mathrm{Na}_{2} \mathrm{O}$ & 4,60 & 1,27 & 2,40 & 0,13 & 0,30 & 2,40 & 0,75 & 0,82 & 0,15 & 3,15 \\
\hline $\mathrm{P}_{2} \mathrm{O}_{5}$ & 0,26 & 0,065 & 0,23 & 0,21 & 0,11 & 0,13 & 0,078 & 0,16 & 0,25 & 0,13 \\
\hline п.п.п. L.O.I & 4,23 & 8,18 & 7,50 & 5,90 & 4,67 & 11,66 & 10,98 & 8,60 & 5,85 & 4,35 \\
\hline $\mathrm{CO}_{2}$ & 1,4 & 4,16 & 4,40 & 0,20 & 0,20 & 6,86 & 6,51 & - & 0,88 & 2,24 \\
\hline общ. total & 0,005 & 0,006 & 0,050 & 5,67 & 4,41 & 0,021 & 0,006 & - & 2,61 & 0,005 \\
\hline
\end{tabular}

Примечание: анализы выполнены в иентральной лаборатории ПГО «Центрказгеология», г. Караганда; n.n.n. - nотери при прокаливании.

Note: analyzes were performed in the central laboratory of the Tsentrkazgeologiya PGO, Karaganda; L.O.I - loss on ignition.

Таблица 2. Расчет привноса (+) и выноса (-) элементов при гидротермально-метасоматических изменениях

Table 2. Calculation of influx (+) and removal (-) of elements during hydrothermal-metasomatic changes

\begin{tabular}{|c|c|c|c|c|c|c|c|c|c|c|}
\hline \multirow[b]{2}{*}{ 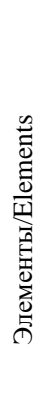 } & \multirow[b]{2}{*}{ 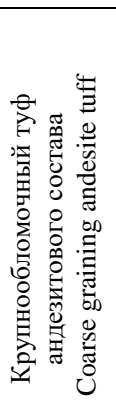 } & \multicolumn{4}{|c|}{$\begin{array}{c}\text { Метасоматиты по крупнообломочным туфам андезитового состава } \\
\text { Metasomatites for coarse graining andesite tuff }\end{array}$} & \multirow[b]{2}{*}{ 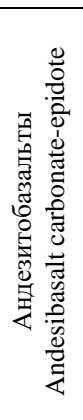 } & \multicolumn{4}{|c|}{$\begin{array}{l}\text { Метасоматиты по андезитобазальтам } \\
\text { Metasomatites for andesibasalt }\end{array}$} \\
\hline & & 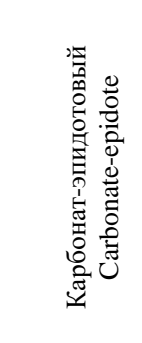 & 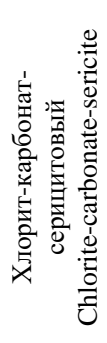 & 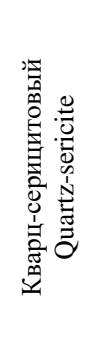 & 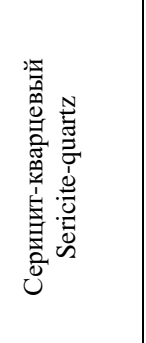 & & 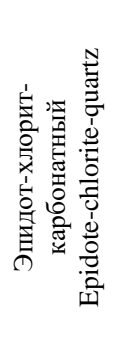 & 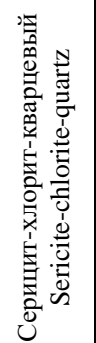 & 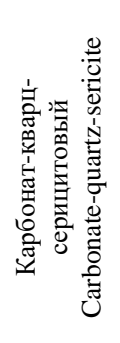 & 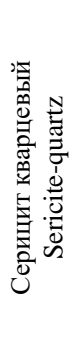 \\
\hline K & 1,21 & $-0,21$ & $+0,35$ & $+3,14$ & $+1,10$ & 0,26 & $+0,28$ & $+1,63$ & $+2,34$ & $+1,84$ \\
\hline $\mathrm{Na}$ & 7,51 & $-3,82$ & $-2,45$ & $-7,33$ & $-7,01$ & 4,15 & $-2,96$ & $-2,86$ & $-3,95$ & $-0,88$ \\
\hline $\mathrm{Ca}$ & 2,32 & $+10,65$ & $+2,99$ & $-1,66$ & $-1,87$ & 8,36 & $+9,81$ & $-3,28$ & $-7,43$ & $-1,29$ \\
\hline $\mathrm{Mg}$ & 4,38 & $-0,03$ & $-0,79$ & $-3,34$ & $-3,78$ & 9,51 & $-3,58$ & $-6,08$ & $-5,77$ & $-4,56$ \\
\hline $\mathrm{Mn}$ & 0,05 & $+0,11$ & $+0,05$ & $-0,04$ & $-0,04$ & 0,21 & $-0,11$ & $-0,12$ & $-0,01$ & $-0,02$ \\
\hline $\mathrm{Fe}^{+2}$ & 3,73 & $-1,10$ & $-0,25$ & $+4,32$ & $-3,03$ & 3,73 & $-1,34$ & $-0,60$ & $+1,05$ & $-2,32$ \\
\hline $\mathrm{Fe}^{+3}$ & 2,01 & $+2,02$ & $-0,56$ & $-1,26$ & $+1,5$ & 3,15 & $+1,31$ & $+0,23$ & $-0,66$ & $-1,98$ \\
\hline $\mathrm{AL}$ & 15,42 & $-1,23$ & $+0,51$ & $-1,88$ & $-4,09$ & 13,88 & $+0,70$ & $+0,36$ & $-0,14$ & $-0,95$ \\
\hline $\mathrm{Ti}$ & 0,35 & $-0,04$ & $-0,19$ & 0,07 & $-0,10$ & 0,36 & $-0,15$ & $+0,03$ & $-0,05$ & $-0,16$ \\
\hline $\mathrm{Si}$ & 49,35 & $-8,86$ & $-0,20$ & $+5,58$ & $+10,83$ & 39,38 & $-2,49$ & $+8,24$ & $+14,23$ & $+7,25$ \\
\hline$P$ & 0,20 & - & $-0,10$ & $-0,11$ & $-0,1$ & 0,10 & - & $-0,01$ & $-0,03$ & - \\
\hline $\mathrm{C}$ & 1,61 & $+3,36$ & $+3,64$ & $-1,43$ & $-1,11$ & 8,25 & $-0,26$ & - & $-7,21$ & $+0,83$ \\
\hline $\mathrm{OH}$ & 15,67 & $+4,71$ & $+2,14$ & $+16,40$ & $+9,25$ & 28,28 & $-1,40$ & $+19,54$ & $+0,55$ & $-7,32$ \\
\hline
\end{tabular}

\section{Выводы}

Формирование пород, слагающих месторождение Абыз, происходило в вулканической островодужной системе активной континентальной окраины. Об этом свидетельствует преобладающий андезитовый состав вулканитов, высокая степень эксплозивности, широкое развитие грубообломочных терригенных пород. Породы, вмещающие оруденение, подверглись ин- 
тенсивным гидротермально-метасоматическим изменениям, относящимся к тектоногенным региональным формациям, представленным пропилитовыми и березитовыми статистически устойчивыми ассоциациями. Последовательность гидротермальнометосамотических образований направлена от пропилитов к березитам. Преобладающий вынос щелочных и щелочно-земельных катионов при высокой активности в реакциях замещения кремния и алюминия, доминирующий кварц-светлослюдистый парагенезис позволяют говорить об образовании серециткварцевых метасоматитов в стадию кислотного выщелачивания. Формирование метасоматитов сопро-

\section{СПИСОК ЛИТЕРАТУРЫ}

1. Hydrothermal alteration of a $1 \mathrm{~km}$ section through the upper oceanic crust, Deep Sea Drilling Project Hole 504B: Mineralogy, chemistry, and evolution of seawater-basalt interactions / J.C. Alt, J. Honnorez, C. Laverne, R. Emmermann // Journal of Geophysical Research. - 1986. - V. 91. - P. 10309-10335.

2. German C.R., Von Damm K.L. Hydrothermal Processes // Treatise on Geochemistry. - 2003. - V. 6-9. - P. 181-222.

3. Classification of VMS deposits: lessons from the South Uralides / R. Herrington, V. Maslennikov, V. Zaykov, I. Seravkin, A. Kosarev, B. Buschmann, J.-J. Orgeval, N. Holland, S. Tesalina, P. Nimis, R. Armstrong // Ore Geology Reviews. - 2005. V. 27 (1-4). - P. 203-237.

4. Mineralogical features of ore diagenites in the Urals massive sulfide deposits, Russia / V.V. Maslennikov, N.R. Ayupova, N.P. Safina, A.S. Tseluyko, I.Y. Melekestseva, R.R. Large, R.J. Herrington, V.A. Kotlyarov, I.A. Blinov, S.P. Maslennikova, S.G. Tessalina // Minerals. - 2019. - V. 9 (3). - P. 1-38.

5. Oxidative dissolution of hydrothermal mixed-sulphide ore: an assessment of current knowledge in relation to seafloor massive sulphide mining / E.K. Fallon, S. Petersen, R.A. Brooker, T.B. Scott // Ore Geology Reviews. - 2017. - V. 86. - P. 309-337.

6. The discovery of native gold in massive sulfides from the Edmond hydrothermal field, Central Indian Ridge and its significance / Z.W. Wu, X.M. Sun, Y.Z. Dai, G.Y. Shi, Y. Wang, Y. Lu, Y.H. Liang // Acta Petrologica Sinica. - 2011. - V. 27 (12). P. 3749-3762.

7. Occurrences and distribution of «invisible» precious metals in sulfide deposits from the Edmond hydrothermal field, Central Indian Ridge / Z. Wu, X. Sun, H. Xu, H. Konishi, Y. Wang, C. Wang, Y. Dai, X. Deng, M. Yu // Ore Geology Reviews. 2016. - V. 79. - P. 105-132

8. Абдулин А.А., Шлыгин А.Е. Металогения и менеральные ресурсы Казахстана. - Алма-Ата: Наука, 1988. - 176 с.

9. Берикболов Б.Р. Меднорудные формации Казахстана. - Алматы: Гылым, 1999. - 196 с.

10. Мазуров А.К. Металлогения и оценка рудоносности металлогенических комплексов островных дуг // Геология и охрана недр. $-2002 .-$ T. 3. - С. 2-10.

11. Мазуров А.К. Металогеническое районирование Казахстана // Известия Томского политехнического университета. - 2005. T. 308. - № 4. - C. 33-39.

12. Dill H.G. The «chessboard» classification scheme of mineral deposits: mineralogy and geology from aluminum to zirconium // Earth-Science Reviews. - 2010. - V. 100 (1-4). - P. 1-420.

13. Massive sulfides of Mount Jourdanne along the super-slow spreading Southwest Indian Ridge and their genesis / B. Nayak, P. Halbach, B. Pracejus, U. Münch // Ore Geology Reviews. - 2014. V. 63. - P. 115-128.

14. Taylor C.D., Lear K.G., Newkirk S.R. A genetic model for the greens creek polymetallic massive sulfide deposit, admiralty island, southeastern Alaska // US Geological Survey Professional Paper. 2010. - V. 1763. - P. 419-429.

15. The metallogeny of Late Triassic rifting of the Alexander terrane in southeastern Alaska and northwestern British Columbia / C.D. Taylor, W.R. Premo, A.L. Meier, J.E. Taggart Jr. // Economic Geology. - 2008. - V. 103 (1). - P. 89-115. вождалось осаждением значительного количества пирита.

В пределах метасоматически измененных пород выделено 13 рудных тел. Морфология рудных тел линзовидная, линзовидно-пластовая. Руды комплексные: медно-свинцово-цинковые с золотом и серебром. Золото наблюдается в виде отдельных зёрен размером $1,5 \ldots 10$ мкм и приурочено к низкотемпературной ассоциации минералов с теллуридами $\mathrm{Pb}$ (алтаит, $\mathrm{PbTe}$ ) и $\mathrm{Bi}$ (раклиджит, $\mathrm{PbBi}_{2} \mathrm{Te}_{4}$ ). Содержание серебра в золотинках достигает $12,5 \%$. Гессит $\left(\mathrm{Ag}_{2} \mathrm{Te}\right)$ встречается в виде тонких зёрен (просечек) с халькопиритом толщиной в несколько мкм в пирите пропилитовой формации.

16. Texture, mineralogy and geochemistry of hydrothermally altered submarine volcanics recovered southeast of Cheshire Seamount, western Woodlark Basin / A. Vishiti, S. Petersen, C.E. Suh, C.W. Devey // Marine Geology. - 2014. - V. 347. - P. 69-84.

17. Щерба Г.Н. Геотектоника и металлогения. - Алма-Ата: Наука, 1988. - $176 \mathrm{c}$.

18. Геодинамическая карта западной части Палеоазиатского океана / Н.А. Берзин, Р.К. Колмак, Н.Л. Добрецов, Л.П. Зоненшайн, Э.3. Чанг // Геология и геофизика. - 1994. - Т. 35 (7-8). C. $8-28$.

19. $\mathrm{Cu}-(\mathrm{Ni}-\mathrm{Co}-\mathrm{Au})$-bearing massive sulfide deposits associated with mafic-ultramafic rocks of the Main Urals Fault, South Urals: Geological structures, ore textural and mineralogical features, comparison with modern analogs / I.Y. Melekestseva, V.V. Zaykov, P. Nimis, G.A. Tret'yakov, S.G. Tessalina // Ore Geology Reviews. 2013. - V. 52. - P. 18-36.

20. Gold-And silver-rich massive sulfides from the semenov-2 hydrothermal field, $13^{\circ} 31.13^{\prime} \mathrm{N}$, Mid-Atlantic ridge: a case of magmatic contribution? / I.Y. Melekestseva, V.V. Maslennikov, G.A. Tret'yakov, P. Nimis, V.E. Beltenev, I.I. Rozhdestvenskaya, S.P. Maslennikova, E.V. Belogub, L. Danyushevsky, R. Large, A.M. Yuminov, S.A. Sadykov // Economic Geology. - 2017. V. 112 (4). - P. 741-773.

21. Mineralogy and geochemistry of metalliferous sedimentary rocks from the upper cretaceous VMS deposits of the eastern pontides (NE Turkey) / M.K. Revan, Y. Genç, O. Delıbaş, V.V. Maslennikov, N.R. Ayupova, O. Zimitoğlu // Turkish Journal of Earth Sciences. - 2019. - V. 28 (2). - P. 299-327.

22. The enrichment characteristic and mechanism of gold-silver minerals in submarine hydrothermal sulfides from the ultra-slowspreading SWIR / Y. Wang, X.-M. Sun, Z.-W. Wu, X.-G. Deng, Y.-Z. Dai, Z.-Y. Lin // Guang Pu Xue Yu Guang Pu Fen Xi/Spectroscopy and Spectral Analysis. - 2014. - V. 34 (12). P. 3327-3332.

23. Physicochemical parameters of magmatic and hydrothermal processes at the Yaman-Kasy massive sulfide deposit, the southern Urals / V.A. Simonov, S.V. Kovyazin, E.O. Terenya, V.V. Maslennikov, V.V. Zaykov, S.P. Maslennikova // Geology of Ore Deposits. - 2006. - V. 48 (5). - P. 369-383.

24. Invisible gold in sulfides from seafloor massive sulfide edifices / N.S. Bortnikov, L.J. Cabri, I.V. Vikentiev, B.R. Tagirov, G. Mc Mahon, Y.A. Bogdanov, O.O. Stavrova // Geology of Ore Deposits. - 2003. - V. 45 (3). - P. 201-212.

25. Geochemical behavior during mineralization and alteration events in the Baiyinchang volcanic-hosted massive sulfide deposits, Gansu Province, China / K. Dong, S. Chen, I. Graham, J. Zhao, P. Fu, Y. Xu, G. Tian, W. Qin, J. Chen // Ore Geology Reviews. 2017. - V. 91. - P. 559-572.

26. Geodiversity of hydrothermal processes along the mid-atlantic ridge and ultramafic-hosted mineralization: a new type of oceanic $\mathrm{Cu}-\mathrm{Zn}-\mathrm{Co}-\mathrm{Au}$ volcanogenic massive sulfide deposit / Y. Fouquet, P. Cambon, J. Etoubleau, J.L. Charlou, H. Ondréas, F.J.A.S. Barriga, G. Cherkashov, T. Semkova, I. Poroshina, M. Bohn, J.P. Donval, K. Henry, P. Murphy, O. // Rouxel Geophysical Monograph Series. - 2013. - V. 188. - P. 321-367.

27. Hydrodynamic modeling of magmatic-hydrothermal activity at submarine arc volcanoes, with implications for ore formation / 
G. Gruen, P. Weis, T. Driesner, C.A. Heinrich, C.EJ. de Ronde // Earth and Planetary Science Letters. - 2014. - V. 404. - P. 307-318

28. Geology and geochemistry of sediment-hosted Hanönü massive sulfide deposit (Kastamonu - Turkey) / K. Günay, C. Dönmez, V. Oyan, N. Yıldırım, E. Ciftçi, H. Yıldız, S. Özkümüş // Ore Geology Reviews. - 2018. - V. 101. - P. 652-674.

29. Further occurrence of brown ores in Kuroko-type deposits in Japan / A. Imai, O. Ishizuka, R. Yamada, H. Miyamoto // Resource Geology. Dept. of Earth and Planetary Science - 2001. - V. 51 (3). P. 263-268.

30. Environmental controls on biomineralization and Fe-mound formation in a low-temperature hydrothermal system at the Jan Mayen Vent Fields / K.C. Johannessen, J. Vander Roost, H. Dahle, S.H. Dundas, R.B. Pedersen, I.H. Thorseth // Geochimica et Cosmochimica Acta. - 2017. - V. 202. - P. 101-123.

31. Ferruginous and manganiferous haloes around massive sulphide deposits of the Urals / V.V. Maslennikov, N.R. Ayupova, R.J. Herrington, L.V. Danyushevskiy, R.R. Large // Ore Geology Reviews. - 2012. - V. 47. - P. 5-41.

32. Chekalin V.M., D'yachkov B.A. Rudny Altai base-metal belt: Localization of massive sulfide mineralization // Geology of Ore Deposits. - 2013. - V. 55 (6). - P. 438-454.
33. Мирошниченко Л.А., Жуков Н.М., Беспаев Х.А. Минерагеническая карта Казахстана // Геология Казахстана. - 2001. T. 3-4. - C. 73-85.

34. Зональность сегментированность и палеогеодинамика девонского вулканического пояса Центрального Казахстана / А.М. Курчавов, М.С. Гранкин, Е.Г. Мальченко, В.И. Жуковский, Б.С. Хамзин, А.К. Мазуров, С.Х. Хамза // Геотектоника. -2000 . - Т. 4. - С. 32-43.

35. Бекжанов Г.Р. Глубинное строение и меднопорфировое оруденение Джунгаро- Балхашской складчатой системы. - АлмаАта: Наука, 1984. -230 с

36. Беспаев Х.Ф., Николаев Л.Г., Тойбазаров М.А. Колчеданнополиметаллические месторождения Прииртышского района. Алма-Ата: Наука, 1988. - 178 с

37. Байболова Ш.Ж., Мазуров А.К., Кряжева Т.В. Геология и типы руд месторождения Абыз // Проблемы геологии и освоения недр: труды XXIII Международного симпозиума имени академика М.А. Усова студентов и молодых ученых, посвященного 120-летию со дня рождения академика К.И. Сатпаева, 120-летию со дня рождения профессора К.В. Радугина. Томск, 2019. - С. 140-142.

Поступила 01.11.2019 2.

\section{Информация об авторах}

Мазуров А.К., доктор геолого-минералогических наук, профессор отделения геологии Инженерной школы природных ресурсов Национального исследовательского Томского политехнического университета.

Pудмин М.A., кандидат геолого-минералогических наук, доцент отделения геологии Инженерной школы природных ресурсов Национального исследовательского Томского политехнического университета.

Байболова Ш.Ж., докторант кафедры геологии и разведки месторождений полезных ископаемых Карагандинского государственного технического университета.

Кряжжева T.B., кандидат геолого-минералогических наук, доцент кафедры геологии и разведки месторождений полезных ископаемых Карагандинского государственного технического университета. 
UDC 553.41: 553.041: 553.22

\title{
MASSIVE SULFIDE DEPOSITS OF ENSIMATIC ISLAND ARCS OF KAZAKHSTAN ON THE EXAMPLE OF ABYZ DEPOSIT
}

\author{
Aleksey K. Mazurov', \\ akm@tpu.ru
}

\author{
Maxim A. Rudmin 1 , \\ rudminma@tpu.ru
} Shynar Zh. Baibolova²,
baibolova-sh@mail.ru

Tatyana V. Kryazheva², kryazheva_t@mail.ru

${ }^{1}$ National Research Tomsk Polytechnic University, 30, Lenin Avenue, Tomsk, 634050, Russia.

2 Karaganda State Technical University of the Department of Geology and Exploration of Mineral Deposits, 56/1, Nursultan Nazarbayev Avenue, Karaganda, 100027, Kazakhstan.

The relevance of the study is caused by the need to highlight new conditions for formation of massive sulfide mineralization ( $\mathrm{Au}-\mathrm{Cu}-\mathrm{Pb}-\mathrm{Ag})$ in late-stage ensimatic island arcs. This study shown that the prospects of ensimatic island arcs are not fully exhausted.

The work aim is to study the petrological, mineralogical and geochemical features of the rocks and ore composition to clarify criteria in forecasting and searching for massive sulfide mineralization in ensimatic island-arc geological formations.

Research methods included studying the composition of rocks and ores using classical mineralogical, petrographic, and mineralographic analyzes and scanning electron microscopy. The chemical composition was determined using silicate analysis. Chemical analysis data were recalculated using the $T$. Bart oxygen method to determine the influx and removal of chemical elements.

The results. The massive sulfide deposits of Kazakhstan were mainly formed in the island-arc geodynamic condition. The island-arc paleosystems are subdivided into ensimatic and ensialic. The formation of the Rudny Altai polymetal belt is associated with ensialic island arcs. The Abyz deposit is associated with the formation of the late stage evolution of ensimatic island arc. The island-arc base was laid on the oceanic crust and is predominantly represented by sedimentary rocks, such as volcanomictic and polymictic sandstones, conglomerates, and siltstones. The main initial rocks of deposit were changed by intense hydrothermal-metasomatic processes, which was reflected in propylization and berezitization. Thirteen ore bodies were formed within the deposit as a result of metasomatic processes. Morphology of ore bodies is complex with lenticular, lenticular-stratum forms. The main minerals of massive sulfide ores are chalcopyrite, pyrite, sphalerite, galena, fahlore, tellurides (altaite, rucklidgeite) and gold inclusions. The silver content in gold is up to $12,5 \%$.

\section{Key words:}

Massive sulfide deposit, ensimatic island arcs, gold ores, hydrothermal-metasomatic changes, forecast and search criteria, Kazakhstan.

\section{REFERENCES}

1. Alt J.C., Honnorez J., Laverne C., Emmermann R. Hydrothermal alteration of a $1 \mathrm{~km}$ section through the upper oceanic crust, Deep Sea Drilling Project Hole 504B: Mineralogy, chemistry, and evolution of seawater-basalt interactions. Journal of Geophysical Research, 1986, vol. 91, pp. 10309-10335.

2. German C.R., Von Damm K.L. Hydrothermal Processes. Treatise on Geochemistry, 2003, vol. 6-9, pp. 181-222.

3. Herrington R., Maslennikov V., Zaykov V., Seravkin I., Kosarev A., Buschmann B., Orgeval J.-J., Holland N., Tesalina S., Nimis P., Armstrong R. Classification of VMS deposits: Lessons from the South Uralides. Ore Geology Reviews, 2005, vol. 27 (1-4), pp. 203-237.

4. Maslennikov V. V., Ayupova N.R., Safina N.P., Tseluyko A.S., Melekestseva I.Y., Large R.R., Herrington R.J., Kotlyarov V.A., Blinov I.A., Maslennikova S.P., Tessalina S.G. Mineralogical features of ore diagenites in the Urals massive sulfide deposits, Russia. Minerals, 2019, vol. 9 (3), pp. 1-38.

5. Fallon E.K., Petersen S., Brooker R.A., Scott T.B. Oxidative dissolution of hydrothermal mixed-sulphide ore: an assessment of current knowledge in relation to seafloor massive sulphide mining. Ore Geology Reviews, 2017, vol. 86, pp. 309-337.

6. Wu Z.W., Sun X.M., Dai Y.Z., Shi G.Y., Wang Y., Lu Y., Liang Y.H. The discovery of native gold in massive sulfides from the Edmond hydrothermal field, Central Indian Ridge and its significance. Acta Petrologica Sinica, 2011, vol. 27 (12), pp. 3749-3762.
7. Wu Z., Sun X., Xu H., Konishi H., Wang Y., Wang C., Dai Y., Deng X., Yu M. Occurrences and distribution of «invisible» precious metals in sulfide deposits from the Edmond hydrothermal field, Central Indian Ridge. Ore Geology Reviews, 2016, vol. 79, pp. $105-132$.

8. Abdulin A.A., Shlygin A.E. Metalogeniya i meneralnye resursy Kazakhstana [Metallogeny and mineral resources of Kazakhstan]. Alma-Ata, Nauka Publ., 1988. 176 p.

9. Berikbolov B.R. Mednorudnye formatsii Kazakhstana [Copper ore formations of Kazakhstan]. Almaty, Gylym Publ., 1999. 196 p.

10. Mazurov A.K. Metallogeniya i otsenka rudonosnosti metallogenicheskikh kompleksov ostrovnykh dug [Metallogeny and orebearing estimation of metallogenic complexes of island arcs]. Geology and Mineral Protection, 2002, vol. 3, pp. 2-10.

11. Mazurov A.K. Metalogenetic zoning of Kazakhstan. Bulletin of the Tomsk Polytechnic University, 2005, vol. 308, no. 4, pp. 33-39. In Rus.

12. Dill H.G. The «chessboard» classification scheme of mineral deposits: Mineralogy and geology from aluminum to zirconium. Earth-Science Reviews, 2010, vol. 100 (1-4), pp. 1-420.

13. Nayak B., Halbach P., Pracejus B., Münch U. Massive sulfides of Mount Jourdanne along the super-slow spreading Southwest Indian Ridge and their genesis. Ore Geology Reviews, 2014, vol. 63, pp. 115-128.

14. Taylor C.D., Lear K.G., Newkirk S.R. A genetic model for the greens creek polymetallic massive sulfide deposit, admiralty island, 
southeastern Alaska. US Geological Survey Professional Paper, 2010, vol. 1763, pp. 419-429.

15. Taylor C.D., Premo W.R., Meier A.L., Taggart Jr. J.E. The metallogeny of Late Triassic rifting of the Alexander terrane in southeastern Alaska and northwestern British Columbia. Economic Geology, 2008, vol. 103 (1), pp. 89-115.

16. Vishiti A., Petersen S., Suh C.E., Devey C.W. Texture, mineralogy and geochemistry of hydrothermally altered submarine volcanics recovered southeast of Cheshire Seamount, western Woodlark Basin. Marine Geology, 2014, vol. 347, pp. 69-84.

17. Shcherba G.N. Geotektonika i metallogeniya [Geotectonics and metallogeny]. Alma-Ata, Nauka Publ., 1988. 176 p.

18. Berzin N.A., Kolmak R.K., Dobretsov N.L., Zonenshayn L.P., Chang E.Z. Geodinamicheskaya karta zapadnoy chasti Paleoaziatskogo okeana [Geodynamic map of the western part of the Paleo-Asian Ocean]. Geology and Geophysics, 1994, vol. 35 (7-8), pp. 8-28.

19. Melekestseva I.Y., Zaykov V.V., Nimis P., Tret'yakov G.A., Tessalina S.G. Cu-(Ni-Co-Au)-bearing massive sulfide deposits associated with mafic-ultramafic rocks of the Main Urals Fault, South Urals: Geological structures, ore textural and mineralogical features, comparison with modern analogs. Ore Geology Reviews, 2013, vol. 52, pp. 18-36.

20. Melekestseva I.Y., Maslennikov V.V, Tret'yakov G.A., Nimis P., Beltenev V.E., Rozhdestvenskaya I.I., Maslennikova S.P., Belogub E. V, Danyushevsky L., Large R., Yuminov A.M., Sadykov S.A. Gold-And silver-rich massive sulfides from the semenov2 hydrothermal field, $13^{\circ} 31.13^{\prime} \mathrm{N}$, Mid-Atlantic ridge: a case of magmatic contribution? Economic Geology, 2017, vol. 112 (4), pp. 741-773.

21. Revan M.K., Genç Y., Delıbaş O., Maslennikov V.V., Ayupova N.R., Zimıtoğlu O. Mineralogy and geochemistry of metalliferous sedimentary rocks from the upper cretaceous VMS deposits of the eastern pontides (NE Turkey). Turkish Journal of Earth Sciences, 2019, vol. 28 (2), pp. 299-327.

22. Wang Y., Sun X.-M., Wu Z.-W., Deng X.-G., Dai Y.-Z., Lin Z.-Y. The enrichment characteristic and mechanism of gold-silver minerals in submarine hydrothermal sulfides from the ultra-slowspreading SWIR. Guang $P u$ Xue Yu Guang $P u$ Fen Xi/Spectroscopy and Spectral Analysis, 2014, vol. 34 (12), pp. 3327-3332.

23. Simonov V.A., Kovyazin S.V, Terenya E.O., Maslennikov V.V, Zaykov V.V, Maslennikova S.P. Physicochemical parameters of magmatic and hydrothermal processes at the Yaman-Kasy massive sulfide deposit, the southern Urals. Geology of Ore Deposits, 2006 vol. 48 (5), pp. 369-383.

24. Bortnikov N.S., Cabri L.J., Vikentiev I.V, Tagirov B.R., Mc Mahon G., Bogdanov Y.A., Stavrova O.O. Invisible gold in sulfides from seafloor massive sulfide edifices. Geology of Ore Deposits, 2003, vol. 45 (3), pp. 201-212.

25. Dong K., Chen S., Graham I., Zhao J., Fu P., Xu Y., Tian G., Qin W., Chen J. Geochemical behavior during mineralization and alteration events in the Baiyinchang volcanic-hosted massive sulfide deposits, Gansu Province, China. Ore Geology Reviews, 2017, vol. 91, pp. 559-572.

26. Fouquet Y., Cambon P., Etoubleau J., Charlou J.L., Ondréas H., Barriga F.J.A.S., Cherkashov G., Semkova T., Poroshina I., Bohn M., Donval J.P., Henry K., Murphy P., Rouxel O. Geodiver- sity of hydrothermal processes along the mid-atlantic ridge and ultramafic-hosted mineralization: A new type of oceanic $\mathrm{Cu}-\mathrm{Zn}-\mathrm{Co}-$ Au volcanogenic massive sulfide deposit. Geophysical Monograph Series, 2013, vol. 188, pp. 321-367.

27. Gruen G., Weis P., Driesner T., Heinrich C.A., de Ronde C.E.J. Hydrodynamic modeling of magmatic-hydrothermal activity at submarine arc volcanoes, with implications for ore formation. Earth and Planetary Science Letters, 2014, vol. 404, pp. 307-318.

28. Günay K., Dönmez C., Oyan V., Yıldırım N., Çiftçi E., Yıldız H., Özkümüș S. Geology and geochemistry of sediment-hosted Hanönü massive sulfide deposit (Kastamonu - Turkey). Ore Geology Reviews, 2018, vol. 101, pp. 652-674.

29. Imai A., Ishizuka O., Yamada R., Miyamoto H. Further occurrence of brown ores in Kuroko-type deposits in Japan. Resource Geology, 2001, vol. 51 (3), pp. 263-268.

30. Johannessen K.C., Vander Roost J., Dahle H., Dundas S.H., Pedersen R.B., Thorseth I.H. Environmental controls on biomineralization and Fe-mound formation in a low-temperature hydrothermal system at the Jan Mayen Vent Fields. Geochimica et Cosmochimica Acta, 2017, vol. 202, pp. 101-123.

31. Maslennikov V.V., Ayupova N.R., Herrington R.J., Danyushevskiy L.V., Large R.R. Ferruginous and manganiferous haloes around massive sulphide deposits of the Urals. Ore Geology Reviews, 2012, vol. 47, pp. 5-41.

32. Chekalin V.M., D'yachkov B.A. Rudny Altai base-metal belt: localization of massive sulfide mineralization. Geology of Ore Deposits, 2013, vol. 55 (6), pp. 438-454.

33. Miroshnichenko L.A., Zhukov N.M., Bespayev Kh.A. Mineragenicheskaya karta Kazakhstana [Mineragenic map of Kazakhstan]. Geology of Kazakhstan, 2001, no. 3-4, pp. 73-85.

34. Kurchavov A.M., Grankin M.S., Malchenko E.G., Zhukovsky V.I., Khamzin B.S., Mazurov A.K., Khamza S.Kh. Zonalnost segmentirovannost i paleogeodinamika devonskogo vulkanicheskogo poyasa Tsentralnogo Kazakhstana [Zoning segmentation and paleogeodynamics of the Devonian volcanic belt of Central Kazakhstan]. Geotectonics, 2000, vol. 4, pp. 32-43.

35. Bekzhanov G.R. Glubinnoe stroenie $i$ mednoporfirovoe orudenenie Dzhungaro- Balkhashskoy skladchatoy sistemy [Deep structure and copper-porphyry mineralization of the DzhungarBalkhash folded system]. Alma-Ata, Nauka Publ., 1984. 230 p.

36. Bespaev H.F., Nikolaev L.G., Toybazarov M.A. Kolchedannopolimetallicheskie mestorozhdeniya Priirtyshskogo rayona [Massive sulfide and polymetallic deposits of the Irtysh region]. AlmaAta, Nauka Publ., 1988. 178 p.

37. Baybolova Sh.Zh., Mazurov A.K., Kryazheva T.V. Geologiya i tipy rud mestorozhdeniya Abyz [Geology and types of ores of the Abyz deposit]. Problemy geologii i osvoeniya nedr. Trudy XXIII Mezhdunarodnogo simpoziuma imeni akademika M.A. Usova studentov $i$ molodykh uchenykh, posvyashchennogo 120-letivu so dnya rozhdeniya akademika K.I. Satpaeva, 120-letiyu so dnya rozhdeniya professors K.V. Radugina [Problems of Geology and Subsoil Development: Proc. of the XXIII International Symposium named after academician M.A. Usov of students and young scientists dedicated to the $120^{\text {th }}$ birthday of academician K.I. Satpayev, $120^{\text {th }}$ birthday of professor K.V. Radugin]. Tomsk, 2019. pp. 140-142.

Received: 1 November 2019.

\section{Information about the authors}

Aleksey K. Mazurov, Dr. Sc., professor, National Research Tomsk Polytechnic University.

Maxim A. Rudmin, Cand. Sc., associate professor, National Research Tomsk Polytechnic University.

Shynar Zh. Baibolova, postgraduate, Karaganda State Technical University.

Tatyana V. Kryazheva, Cand. Sc., associate professor, Karaganda State Technical University. 